Macmillan Building and Surveying Series

Series Editor: Ivor H. Seeley

Emeritus Professor, Nottingham Trent University

Accounting and Finance for Building and Surveying A.R. Jennings

Advanced Building Measurement, second edition Ivor $\mathrm{H}$. Seeley

Advanced Valuation Diane Butler and David Richmond

Applied Valuation, second edition Diane Butler

Asset Valuation Michael Rayner

Building Economics, fourth edition Ivor $\mathrm{H}$. Seeley

Building Maintenance, second edition Ivor $\mathrm{H}$. Seeley

Building Maintenance Technology Lee How Son and George C.S. Yuen

Building Procurement Alan E. Turner

Building Project Appraisal Keith Hutchinson

Building Quantities Explained, fourth edition Ivor H. Seeley

Building Services G. Hassan

Building Surveys, Reports and Dilapidations Ivor H. Seeley

Building Technology, fifth edition Ivor $\mathrm{H}$. Seeley

Civil Engineering Contract Administration and Control, second edition Ivor $\mathrm{H}$. Seeley

Civil Engineering Quantities, fifth edition Ivor H. Seeley

Commercial Lease Renewals - A Practical Guide Philip Freedman and Eric F. Shapiro

Computers and Quantity Surveyors A.J. Smith

Conflicts in Construction - Avoiding, Managing, Resolving Jeff Whitefield

Constructability in Building and Engineering Projects A. Griffith and A.C. Sidwell

Construction Contract Claims Reg Thomas

Construction Law Michael F. James

Contract Planning and Contract Procedures, third edition B. Cooke

Contract Planning Case Studies B. Cooke

Cost Estimates of Structures in Commercial Buildings Surinder Singh

Design-Build Explained D.E.L. Janssens

Development Site Evaluation N.P. Taylor

Economics and Construction Andrew Cooke

Environment Management in Construction Alan Griffith

Environmental Science in Building, third edition R. McMullan

European Construction - Techniques and procedures B. Cooke and G. Walker

Facilities Management Alan Park

Greener Buildings - Environmental Impact of Property Stuart Johnson

Housing Associations Helen Cope

Housing Management - Changing Practice Christine Davies (Editor)

Information and Technology Applications in Commercial Property Rosemary Feenan and

Tim Dixon (Editors)

Introduction to Building Services, second edition E.F. Curd and C.A. Howard

Introduction to Valuation, third edition D. Richmond

Marketing and Property People Owen Bevan

Principles of Property Investment and Pricing, second edition W.D. Fraser

Project Management and Control David Day

Property Finance David Isaac

Property Development - Appraisal and Finance David Isaac 


\author{
Property Valuation Techniques David Isaac and Terry Steley \\ Public Works Engineering Ivor H. Seeley \\ Quality Assurance in Building Alan Griffith \\ Quantity Surveying Practice Ivor H. Seeley \\ Recreation Planning and Development Neil Ravenscroft \\ Resource Management for Construction M.R. Canter \\ Small Building Works Management Alan Griffith \\ Structural Detailing, second edition P. Newton \\ Sub-Contracting under the JCT Standard Forms of Building Contract Jennie Price \\ Urban Land Economics and Public Policy, fifth edition P.N. Balchin, G.H. Bull and \\ J.L. Kieve \\ Urban Renewal - Theory and Practice Chris Couch \\ 1980 JCT Standard Form of Building Contract, third edition R.F. Fellows \\ Value Management in Construction B. Norton and W. McElligott
}

\footnotetext{
Series Standing Order

If you would like to receive future titles in this series as they are published, you can make use of our standing order facility. To place a standing order please contact your bookseller or, in case of difficulty, write to us at the address below with your name and address and the name of the series. Please state with which title you wish to begin your standing order. (If you live outside the United Kingdom we may not have the rights for your area, in which case we will forward your order to the publisher concerned.)

Customer Services Department, Macmillan Distribution Ltd Houndmills, Basingstoke, Hampshire, RG21 2XS, England.
} 


\section{Introduction to Building Services}

Second Edition

E.F. Curd and C.A. Howard School of the Built Environment Liverpool John Moores University

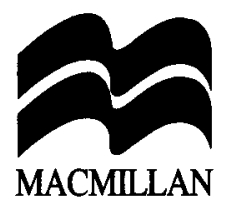


C.A. Howard 1988

(C) E.F. Curd and C.A. Howard 1996

All rights reserved. No reproduction, copy or transmission of this publication may be made without written permission.

No paragraph of this publication may be reproduced, copied or transmitted save with written permission or in accordance with the provisions of the Copyright, Designs and Patents Act 1988, or under the terms of any licence permitting limited copying issued by the Copyright Licensing Agency, 90 Tottenham Court Road, London W1P 9HE.

Any person who does any unauthorised act in relation to this publication may be liable to criminal prosecution and civil claims for damages.

First edition 1988

Second edition 1996

Published by

MACMILLAN PRESS LTD

Houndmills, Basingstoke, Hampshire RG21 6XS

and London

Companies and representatives

throughout the world

ISBN 978-0-333-59911-2

ISBN 978-1-349-13298-0 (eBook)

DOI 10.1007/978-1-349-13298-0

A catalogue record for this book is available from the British Library.

$\begin{array}{rrrrrrrrrr}10 & 9 & 8 & 7 & 6 & 5 & 4 & 3 & 2 & 1 \\ 05 & 04 & 03 & 02 & 01 & 00 & 99 & 98 & 97 & 96\end{array}$




\section{CONTENTS}

Preface

viii

1 Cold water installations: supply and distribution

Introduction

Water supply

Nature of water

Supplies to low-rise buildings

Supplies to high-rise buildings

Pipe sizing

Example

Questions

References

2 Domestic hot water generation and distribution

Introduction

Electric immersion heaters

DHW generation by boiler systems

Point-of-use domestic hot water supply

Primatic indirect hot water cylinder

Unvented hot water systems

Domestic hot water by solar energy

Domestic hot water temperature

Questions

References

3 Disposal services: sanitary appliances, drainage above and below ground, solid waste storage

Introduction

Sanitary appliances

Drainage above ground

Drainage below ground

Refuse disposal

Questions

References

\section{Types of heating system}

Fundamental considerations

Comfort factors

Heating systems

Utilization subsystem

Energy conversion subsystem

Fuels

Firing methods

Distribution subsystem 
$\begin{array}{lr}\text { Control subsystem } & 60\end{array}$

\begin{tabular}{lr} 
Solar heating & 61 \\
\hline
\end{tabular}

$\begin{array}{lr}\text { Electricity } & 62\end{array}$

$\begin{array}{lr}\text { District heating } & 62\end{array}$

$\begin{array}{lr}\text { Combined heat and power } & 63\end{array}$

$\begin{array}{lr}\text { Questions } & 63\end{array}$

$\begin{array}{lr}\text { References } & 64\end{array}$

5 Ventilation, air conditioning and refrigeration $\quad 66$

$\begin{array}{lr}\text { Ventilation } & 66\end{array}$

$\begin{array}{lr}\text { Methods of air distribution } & 68\end{array}$

$\begin{array}{lr}\text { Air change rate } & 69\end{array}$

$\begin{array}{lr}\text { Air-conditioning systems } & 70\end{array}$

$\begin{array}{ll}\text { Basic refrigeration process } & 76\end{array}$

$\begin{array}{lr}\text { Heat pumps } & 78\end{array}$

\begin{tabular}{lr} 
Fans & 78 \\
\hline
\end{tabular}

$\begin{array}{lr}\text { Filters } & 80\end{array}$

$\begin{array}{lr}\text { Ductwork } & 80\end{array}$

$\begin{array}{lr}\text { Questions } & 81\end{array}$

$\begin{array}{lr}\text { References } & 81\end{array}$

6 Electrical services for buildings $\quad 82$

\begin{tabular}{lr} 
Electricity & 82 \\
\hline
\end{tabular}

$\begin{array}{lr}\text { Electrical generation and distribution } & 83\end{array}$

$\begin{array}{lr}\text { Distribution of electricity in buildings } & 85\end{array}$

$\begin{array}{lr}\text { Electrical regulations } & 92\end{array}$

$\begin{array}{lr}\text { Questions } & 94\end{array}$

$\begin{array}{lr}\text { References } & 94\end{array}$

$\begin{array}{llr}7 \text { Gas installations } & 95\end{array}$

\begin{tabular}{lr} 
Introduction & 95 \\
\hline
\end{tabular}

$\begin{array}{lr}\text { Connection of the gas supply } & 96\end{array}$

\begin{tabular}{lr} 
Burner types & 97 \\
\hline
\end{tabular}

$\begin{array}{lr}\text { Flues } & 98\end{array}$

$\begin{array}{lr}\text { Questions } & 101\end{array}$

$\begin{array}{lr}\text { References } & 101\end{array}$

8 Services access, lifts and escalators, fire-fighting equipment,
external access to buildings, and services costs

$\begin{array}{lr}\text { Introduction to service integration } & 102\end{array}$

$\begin{array}{lr}\text { Structural accommodation of services } & 102\end{array}$

$\begin{array}{lr}\text { Non-structural accommodation methods } & 104\end{array}$

$\begin{array}{lr}\text { Lift and escalator installations } & 107\end{array}$

$\begin{array}{lr}\text { Fire-fighting installations } & 112\end{array}$

Access for exterior maintenance $r$

$\begin{array}{lr}\text { Services: cost considerations } & 120\end{array}$

$\begin{array}{lr}\text { Questions } & 124\end{array}$

$\begin{array}{lr}\text { References } & 125\end{array}$ 
Appendices

$\begin{array}{lr}\text { A Interpretation of drawn information } & 127\end{array}$

$\begin{array}{lr}\text { B Units and equations } & 134\end{array}$

Index 


\section{PREFACE}

This book is intended as a textbook for use by students of quantity surveying, building surveying, estate management, architecture and building up to degree level. It can also be used as an introduction for students of building services engineering.

Some students find the important topic of building services difficult to grasp. This is because they are unable to associate it with their future profession, or relate it to the environmental science topics covered in the course of their study.

The method of treatment in this book is to provide individual students or whole classes with a teaching approach of sufficient clarity that the student, presumably unfamiliar with the topic, will not be confused, and to give sufficient coverage of the topics to provide solid theoretical groundwork together with some knowledge of practice.

This second edition has been prepared in order to bring the book up to date with recent developments in the field since the first edition was written.

All chapters have been revised, and new chapters added, together with an appendix covering some of the basic equations used in building services engineering. An important new feature, which the authors believe will find favour with both lecturers and students, is the model questions given at the end of each chapter.

As British, European and international standards, as well as the UK Building Regulations, have changed considerably since the first edition, this new edition allows these to be brought up to date. It must be remembered, however, that all BS and CEN (European) standards are in a state of flux, and reference should always be made to the current standards. It is recommended that Environmental Science in Buildings by Randall McMullan (Macmillan, 3rd edn, 1992) is read in conjunction with this book in order to clarify and augment the relationship between environmental science and building services.

E.F. Curd

C.A. Howard 1996 